\title{
降雪地域における2型糖尿病患者の 運動継続に関する追跡調查
}

\author{
Follow-up Survey about Exercise Continuation of Patients with \\ Type 2 Diabetes Mellitus in Snowfall Area
}

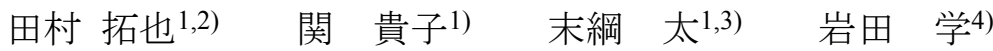 \\ TAKUYA TAMURA, RPT ${ }^{1,2)}$, TAKAKO SEKI, RPT ${ }^{1)}$, FUTOSHI SUETSUNA, MD ${ }^{3)}$, MANABU IWATA, MD ${ }^{4)}$ \\ 1) Department of Physical Therapy, Hachinohe City Hospital: 1 Bishamondaira, Tamukai, Hachinohe-City, Aomori 031-8555, \\ Japan.TEL +81178-72-5260FAX+81178-72-5115E-mail tt.stage@htv-net.ne.jp \\ 2) Hirosaki University Graduate School of Health Sciences Health Sciences (Master Course), Division of Comprehensive Rehabil- \\ itation Sciences Department of Physical Therapy \\ 3) Department of First Orthopaedics, Hachinohe City Hospital \\ 4) Department of Disability and Health, Division of Health Sciences, Graduate School of Health Sciences, Hirosaki University
}

Rigakuryoho Kagaku 24(3): 353-358, 2009. Submitted Nov. 14, 2008. Accepted Jan. 19, 2009.

ABSTRACT: [Purpose] We surveyed whether exercise continuation after hospital discharge of type II diabetes mellitus patients was improved by teaching indoor exercises in a snowfall area in winter, and investigated the relationship between exercise frequency and glycemic control. In addition, we examined the relationship between continuation of the exercise therapy and the continuation of diet therapy. [Methods] Subjects were 101 patients with type II diabetes mellitus. For these patients, we conducted a monitor-type exercise therapy. One year later, we asked whether the patients continued the exercise by telephone. [Results] $88 \%$ of the patients continued the exercise. As for the patients who exercised frequently, glycemic control was good. A significant relationship was observed between diet therapy and exercise therapy. [Conclusion] In a snowfall area, indoor exercise guidance improved exercise continuation of patients with type II diabetes mellitus.

Key words: diabetes mellitus exercise therapy, snowfall area, retrospective study

要旨：〔目的〕本研究の目的は，降雪地域において，冬期間でも行える運動を指導した 2 型糖尿病患者の退院後の運 動継続度および運動頻度の違いと血糖コントロールの関連性を調查することである。また併せて運動療法の継続と 食事療法の実施状況との関連性を検討した。〔方法〕対象は運動処方された 2 型糖尿病患者 101 名とした。これらの 患者に対し, 我々理学療法士が監視型運動療法を実施し, 患者が退院してから一年後の運動継続度を, 電話アンケー トにて追跡調査した。〔結果〕対象患者の $88 \%$ が退院一年後も運動を継続していた。また運動頻度が高い患者ほど血 糖コントロールが良好であった。また食事療法と糖尿病運動療法との間に，有意な関連性が認められた。結語〕降 雪地域では, 冬期間も継続的に行える運動を2型糖尿病患者に指導することにより, 降雪期間に運動療法として「踏 み台昇降・足踏み・歩行」をする患者が多く, 一般的に言われている運動継続度よりも向上したことが示唆された。 キーワード : 糖尿病運動療法, 降雪地域, 後乃向き研究

1) 八戸市立市民病院 リハビリテーション科：青森県八戸市田向毘沙門平1番地（テ031-8555）TEL 0178-72-5260

FAX 0178-72-5115

2) 弘前大学大学院 医学系研究科保健学専攻総合リハビリテーション領域理学療法学分野

3) 八戸市立市民病院 第一整形外科

4) 弘前大学大学院 保健学研究科健康支援科学領域障害保健学分野

\section{受付日 2008年11月14日受理日 2009年1月19日}




\section{I.はじめに}

血糖が高い状態が続くと，主として血管が侵される 慢性合併症が引き起こされる。その中には糖尿病特有 の合併症（網膜症, 腎症, 神経障害) と, 糖尿病によっ て促進される動脈硬化とがある。動脈硬化症は心筇梗 塞や脳梗塞の原因となる ${ }^{1)}$ 。厚生労働省は「生活習慣病 の医療費は国民医療費の 3 分の 1 占める。生活習慣の 変化などから, 脳卒中や心筋梗塞などの発症の危険性 が高くなる糖尿病患者らが急増している。医療費削減 のためにはこうした疾患の発症や悪化予防が久かせな いとして, 国は 2015 年までに糖尿病などの生活習慣病 患者・予備群の $25 \%$ 減（08年比）を目指している。」と 報告している2)。

糖尿病の治療戦略は, 糖尿病の病型, 病態, 代謝障害 の程度により異なる。例えば, (1)インスリン依存状態で はインスリン治療を行う。インスリン非依存状態におい ても, 妊娠時, 全身管理が必要な外科手術, 重篤な感染 症の際にはインスリンで治療する。また, 経口血糖降下 薬によっても血糖コントロールの目標が得られない場 合はインスリン治療を行う。(2)インスリ非依存状態に おいては，十分な食事，運動療法を 2 ～3 月間行って も良好な血糖コントロールが得られない場合は, 経口血 糖降下薬により治療する。代謝障害の程度によっては, 初めからインスリンや経口血糖降下薬の薬物療法を食 事療法, 運動療法に加えて開始する ${ }^{3)}$ 。運動療法は食事 療法と共に重要な基本的治療分野であり, 運動介入によ りインスリン感受性が有意に増加するという治療効果 のエビデンスは確立されている4)。「2型糖尿病に対する 運動」5) と題した欧米の報告では, 2 型糖尿病の人には 通常有酸素運動が推奨されている。しかしながら, 一般 的に運動継続度は低く, 結果として経口血糖降下薬やイ ンスリン注射などの薬物療法の介入がなされる場合が 少なくない。日本国内でも多数の糖尿病運動療法の継続 度向上に関する工夫のなどがなされているが, 未だ十分 な糖尿病運動療法の継続度向上には至っていない。また いくつかの研究においては, 食事または行動の変化ある いはその両方と併せて運動介入の有用性が評価されて おり, 食事療法と運動療法の効果の区別がなされていな (7)。

糖尿病運動療法は, 糖尿病療養指導士認定機構の報 告 ${ }^{8)}$ によると, 退院後の継続率は $40 \sim 60 \%$ とされ, 食 事療法や薬物療法の継続率に比べ格段に低くなってい る。そのため, 糖尿病の教育入院などを実施している 病院などでは, 理学療法士が積極的に関与し, 個別の
運動指導や集団指導を行うことにより，継続率の向上 を図る努力がなされている9)。しかしながら，十分な効 果が得られていないのが実情とされる。

糖尿病運動療法が継続困難な理由としては, 多数の 要因が考えられるが, 清水らによると, 「処方された運 動強度が強すぎた」,「運動時間帯が生活と合わない, 「忙しくて時間が取れない」, 「仕事や家事との両立が困 難である」,「趣味と合わない, 「身体に支障が出た」, 「最終目標が見えない,「高齢になった」,「運動する気 持ちにならない」といった理由が報告されている10)。 その他に, 当院のある降雪地域などでは, 冬期間の屋 外運動の施行が難しくなることも, 運動継続度を低下 させる要因の一つと考えられる。

上記のような状況を踏まえて, 当院では糖尿病運動 療法に理学療法士が積極的に関与し, 心肺運動負荷試

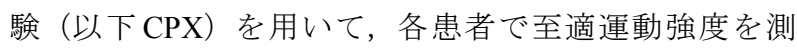
定し，それを基に，歩行や自転車エルゴメータといっ た一般的な運動の他に，冬期間に屋内で手軽にできる 踏み台運動や足踏み運動の指導を行ってきた。

本研究の目的は, 当院で行ってきた糖尿病運動療法 指導方法が，運動継続に効果があったかどうかを調查 し, 従来の運動療法継続率と比較検討することである。 また，併せて運動療法の継続と食事療法の実施状況と の関連性について調査した。

\section{II. 対象と方法}

対象は 2005 年 4 月から 2008 年 1 月までに運動処方さ れた 2 型糖尿病患者 101 例であり，筆者の勤務する病院 であるため降雪地域に在住する者である。内訳は男性 60 例 (平均年齢 $48.1 \pm 13.1$ 歳), 女性 41 例 (平均年齢 53.9 \pm 14.9 歳) であった。なお, 本研究の概要は, 当院倫理 委員会及び弘前大学大学院医学系研究科倫理委員会で 承認されており, 対象者からインフォムドコンセント を得て実施された。

対象となった患者に対し, 理学療法処方から退院ま で監視型運動療法を開始した。運動療法は午前・午後

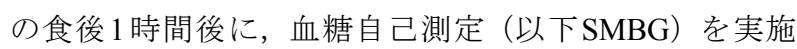
した後, 準備体操及びCPX に基づいた各患者での至適 運動強度での有酸素運動を $15 \sim 60$ 分実施した。有酸素 運動の種類は, 患者本人の嗜好もふまえて, 歩行やト レッドミル，自転車エルゴメータといった一般的な運 動方法に加えて, 降雪期間に室内で施行可能な踏み台 運動や足踏み運動の指導を行った。

これらの患者が退院一年後に運動継続できているか 
調査票)
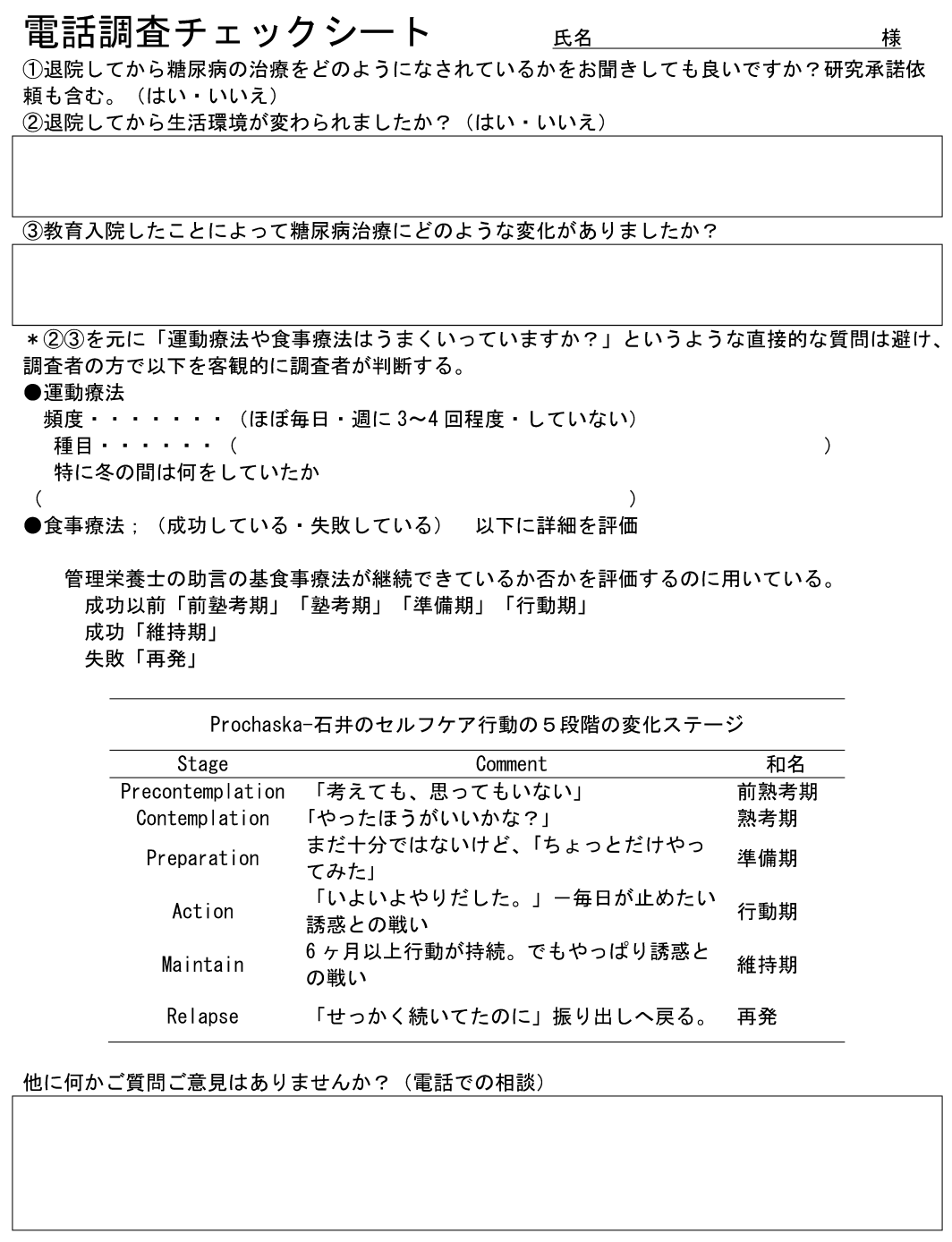

図1 調査票

を電話で追跡調査を行った。一年後の追跡調查である ため, 前向き研究では結果が出るのは一年後となって しまうため, 同意の得られた患者を対象に後ろ向き研 究で行った。調査では退院後の生活がどのように行わ れているかを電話調査チェックシート（調査票）(図 1) にて評価した。食事療法の継続度の調査には石井が報 告している変化ステージ11) を採用した。そして一人の 理学療法士が電話調査をしているのをもう一人の理学 療法が横で聞くことにより調査者の主観が入らないよ うに, 客観的に判断するように配慮した。その調査結 果から, 冬季の降雪期間を含めた運動維持ができてい
るか, 食事療法が継続できているかを検証した。糖尿 病の血糖コントロールは通常 HbA1c という検査值で評 価している。HbA1c とは, 赤血球 (へモグロビン) がつ くられたときから現在までの血糖值に比例し, その值 は過去 1 2 ケの血糖值の平均值を反映する。正常範 囲は下限值 $4.3 \%$ ，上限值 $5.8 \%$ であり，この $\mathrm{HbA} 1 \mathrm{c}$ の值 が評価基準となる。すなわち $5.8 \%$ 未満が「優」，5.8〜 $6.5 \%$ 未満が「良」, $6.5 \sim 8.0 \%$ が「可」, $8.0 \%$ 以上が「不 可」と分類され, 最低限 HbA1c を $6.5 \%$ にコントロール することが糖尿病の治療目標となる。運動を継続して いる患者と継続できていない患者の糖尿病患者の血糖 
表1 運動療法頻度別のHbA1c変化傾向

\begin{tabular}{lcccr}
\hline & ほぼ毎日 & 週に数回 & やっていない & 合計 \\
\hline 改善 & 30 & 9 & 0 & 39 \\
改善傾向 & 21 & 29 & 6 & 56 \\
悪化 & 0 & 0 & 6 & 6 \\
\hline 合計 & 51 & 38 & 12 & 101 \\
\hline
\end{tabular}

表2 運動頻度別食事療法の継続の有無

\begin{tabular}{lccccc}
\hline & ほぼ每日 & 週に3〜4 回 & やっていない & 合計 \\
\hline 食事療法成功 & $44(86.2 \%)$ & $31(81.5 \%)$ & $4(33.3 \%)$ & 79 \\
食事療法失敗 & $7(13.7 \%)$ & $7(18.4 \%)$ & $8(66.6 \%)$ & 22 \\
\hline 合計 & 51 & 38 & 12 & 101 \\
\hline
\end{tabular}

表3 降雪期間の運動種目（複数回答可）

\begin{tabular}{lcccccc}
\hline & 歩行 & 踏み台 & エルゴ & トレッドミル & ジム & その他 \\
\hline ほぼ毎日 & 16 & 22 & 10 & 8 & 10 & 2 \\
週に数回 & 19 & 15 & 2 & 1 & 4 & 1 \\
\hline
\end{tabular}

コントロールの指標である HbA1c（正常值 $4.3 \%$ ～ 4.8 $\%$ ）変化を比較するため, 今回は運動指導から 1 年後の $\mathrm{HbA} 1 \mathrm{c}$ 変化を, 「(1)改善 : 運動指導時より改善し, なお かつHbA1c が $6.5 \%$ 未満, (2)改善傾向 : 運動指導時より 改善しているが $\mathrm{HbA} 1 \mathrm{c}$ が $6.5 \%$ 以上, (3)悪化: 運動指導 時より悪化している」と定め, クルスカルワリス検定 を用いて統計学的に分析した。また運動療法と食事療 法の関連性については, カイ 2 乗検定を用いて統計学 的に検証した。なおいずれの検定も, 危険率 $5 \%$ 未満を 有意とした。

\section{III. 結 果}

電話調査の結果, 運動をほぼ毎日行っている群（1 群）が 51 名で $50 \%$, 週に数回運動を行っている群（2 群）が 38 名で $38 \%$, 運動を行っていない群（3群）が 12 名で $12 \%$ と, 1 群と 2 群を併せると 89 名 $88 \%$ の患者が運 動を継続していた。また各群で運動指導 1 年後の HbA1c 変化を見てみると, 1 群では改善 30 例, 改善傾向 21 例, 悪化 0 例であった。2 群では改善 9 例, 改善傾向 29 例, 悪化 0 例であった。3 群では改善 0 例, 改善傾向 6 例, 悪 化6例であった。
運動継続できている患者群（1群・2群）とできてい ない患者群 (3 群) の運動指導 1 年後の血糖コントロー ルの指標である HbA1cの值を, 3 群を比較できるクルス カルワリス検定を用いて統計解析したところ, 3 群の間 に $<<0.001$ と有意差が認められた。このことから, HbAlc 変化と運動頻度には関連性が認められた（表1)。また, 食事療法と運動療法の継続率も同一101名の患者で力 イ 2 乗検定にて, $\mathrm{p}<0.001$ と有意差が認められ, 運動療 法の継続率と食事療法の継続率には関連性が認められ た（表2）。

運動療法を継続していた患者のコメントでは，降雪 期間でも可能な踏み台運動の指導やCPX えた指導が良かったという意見が101名中72名と多かっ た。実際に運動種目を調査してみる（複数回答可）と， 1 群（ほぼ毎日行っている）の患者では, 踏み台 22 名, 歩行 16 名と半数以上で継続していた。またこの群では, 自転車エルゴメータ 10 名, トレッドミル 8 名といった 降雪期間も屋内で続けられるように, 器具を購入して 室内運動を行っていた患者もみられた（表3）。2群（週 に数回行っている）の患者は, 歩行 19 名・踏み台 15 名 が主体となっていた（表3）。 


\section{IV. 考 察}

今回の調查結果は, 日本糖尿病指導士の報告 8) によ る「糖尿病運動療法の退院後継続率は $40 \sim 60 \%$ とされ る」という報告の割合を上回っていた。これは, 降雪 期間でも継続できる徹底した踏み台や足踏み運動を指 導したことにより，気候に左右されず運動療法が行え たためと考えられる。これは北日本や日本海側特有の 降雪による屋外運動の中断を防ぐ対策の一つになるか もしれない。また糖尿病教育入院中に, SMBG や CPX に基づいた監視型運動療法を実施したところ, 患者が 自身の血糖変動を実際の数值で確認できたことなどが 動機付けとなり，運動継続率が向上した可能性もある。 退院後の食事療法と運動療法は, どちらも自己管理を 要する点では共通点が多く, 本研究結果でも, 運動療 法と食事療法の継続には関連性が認められた。

全国的には, 糖尿病運動療法での SMBG や CPX は確 立していない。その理由として,リハビリテーション 診療報酬で糖尿病患者を個別運動したとしても, コス 卜を取ることができず, 病院経営上損失になるためで あろう。しかし, 糖尿病における運動指導は有効なも のと考える。藤沼らは「体力が低い方には軽い運動で も大きな負担になる場合があり，負担が大きすぎると 辛い運動となり，意欲が削がれてしまう」12) と報告して いる。浅野らは, 「運動処方は安全の限界を超えず行わ なければならない13) と示唆している。また糖尿病専門 医研修ガイドブックには「最大酸素摂取量に影響しな いような軽度の身体トレーニングでも長期にわたって 実施すれば個体のインスリン感受性を改善できる」 ${ }^{14)}$ と 記載されている。筆者らの引用文献であるが，2型糖尿 病患者を対象として, 臨床現場で一般的なカルボーネ ンの式を用いた運動処方では, 運動強度が強すぎるこ とをすでに報告している15)。以上のことから，糖尿病 運動処方においても, 症例ごとに効果的な至適運動強 度が異なるため, 継続率向上のためにも個別運動指導 が必要であると考えられる。

佐藤ら ${ }^{16)}$ は「糖尿病運動療法の意義がインスリン感 受性の改善と筋肉という代謝活性組織の強化による高 血糖状態の改善と高インスリン血症の改善, それに伴 う外因性インスリンの節約がもたらす糖尿病性血管病 変の防止, 寸なわち, 糖尿病性合併症の発現, 進展の 阻止にあること」であると報告しており，運動継続の 意義は非常に重要である。これまでに, 糖尿病運動療 法の継続度に関する論文は数多くあるものの, 降雪期 間の糖尿病運動療法に言及した報告は少ない17)。確か
に降雪は特定の地域の問題ではあるが，一定期間屋外 運動を阻害する要因は, 梅雨などの降雪以外の気象条 件も考えられる。その意味において降雪地域における 通年の運動継続度を調查した本研究結果が, この分野 での研究推進に繋がることを期待する。

また運動療法を継続させる為に, 海外ではコミュニ ティヘルスセンターを利用しているという報告 ${ }^{18,19)}$ も ある。しかし日本では糖尿病運動療法は基本診療料に 含まれ，診療報酬上算定できない領域である 200 。海外 では国によって違うものと思われるが，国民健康保険 や社会保険の存在しないアメリカなどでは自由診療で 患者と理学療法士が契約成立すれば，報酬は取ること も可能である。日本において, 糖尿病運動療法そのも のが普及しない原因は, このような病院経営上の問題 も絡んでいるものと思われる。今後, 徹底した運動療 法指導を行うことにより, 糖尿病運動療法の継続度が 向上すれば，合併症である細血管障害（神経障害・網 膜症・腎症)，大血管障害（脳梗塞・心筋梗塞）の罹病 患者が減少することが期待できる。

血糖変動による動機付けや自己管理を予測的に考察 した。しかし本研究の限界として, 本研究の被験者と して同意し参加してくれた患者が，筆者が勤務してい る病院の内分泌糖尿病内科に定期的に通院している, 比較的自己管理ができている患者群であったことが, 高い運動継続率のバイアスとなったことは否定できな い。また電話調查という方法も, 客観性に配慮したと は言え, 患者の真の生活状況を捉えられたかどうかに 関しては, 最適とは言い難い。すなわち本研究結果を 持ってして,2型糖尿病患者全体の動向であると断言で きないところが本研究の限界であろう。また今後の課 題としては, 運動療法処方の有無にかかわらず, 全て の 2 型糖尿病患者をフォローできる体制を構築するこ とであり, それにより更に一般的な疫学デー夕を提供 できるものと考えられる。

\section{引用文献}

1) 葛谷 健 : 糖尿病の治療の進歩 これまでの治療, これから の治療Treatment of diabetes mellitus: Past, present and future. 藍 野学院紀要, 2004, 18: 17-13.

2) 厚生労働省: 健康局 (平成20年4月審査分) http://www.mhlw. go.jp/bunya/kenkou/seikatsu/index.html（閲覧日 2008 年 10 月 10 日).

3) 日本糖尿病学会: 科学的根拠に基づく糖尿病ガイドライン第 2版，2糖尿病治療の目標と指針，2007, p13.

4) 日本糖尿病学会, 学童糖尿病検診研究会: 尿糖陽性坚童生徒 の事後措置ガイドブック， 2002. 
5) Thomas DE, Elliott EJ, Naughton GA: Exercise for type 2 diabetes mellitus. Cochrane Database Syst Rev, 2006, Issue 3.

6) 鍋 谷昭, 徳永幹雄 : 運動継続のための新しいアプローチ. 健康科学, 2001, 23: pp103-116.

7) Thomas DE, Elliott EJ, Naughton GA, et al.: Exercise for type 2 diabetes mellitus. Cochrane Database Syst Rev, Metabolic and Endocrine Disorders 2006.

8) 日本糖尿病療養指導士認定機構（編）：日本糖尿病療養指導 士受験ガイドブック糖尿病療養指導士の学習目標と課題. 2003, p89.

9) 野村卓生, 榎 勇人, 岡崎里南 - 他 : 糖尿病教育入院後の運 動療法継続について理学療法士介入前後の比較. 理学療法 学, 2003, 30: 36 .

10) 清水弘明 : 実践糖尿病運動療法「運動を継続していただくた めに」. 診断と治療社，東京，2004, p39.

11) 石井 均: 糖尿病, 耐糖能障害, メタボリックシンドローム 患者への心理・行動的援助. 医学のあゆみ, 2007, 220(13): 1214-1218.

12) 浅野弘明, 藤沼宏彰 : 実践糖尿病運動療法. 紀伊國屋書店, 東京, $2004, \mathrm{p} 50$.

13) 浅野弘明, 藤沼宏彰 : 実践糖尿病運動療法. 紀伊國屋書店, 東京, 2004, p59.
14) 日本糖尿病学会（編著）: 糖尿病専門医研修ガイドブック改 訂第3版 第7章 運動療法. 診断と治療社，東京，2006, p95.

15) 田村拓也, 関 貴子, 岩田 学・他：2型糖尿病患者への呼 気ガス分析 (CPX) を用いた運動処方の検討Prescription of exercise with exhalation gas analysis (CPX) for patients with type 2 diabetes mellitus. 日本心臓リハビリテーション学会誌（印刷 中).

16) 佐藤秀一, 庄子美和, 加藤厚子・他 : 脳血管障害を合併した 糖尿病患者の代謝改善と運動効果. 理学療法学, 1991, 18(4): 405-412.

17) 森井まゆみ:てこずり糖尿病冬季の療養指導のポイントは? 肥満と糖尿病, 2004, 3(2): 276-277.

18) Chin MH, Cook S, Jin L, et al.: LinksBarriers to providing diabetes care in community health centers. Diabetes Care, 2001, 21: 268-274.

19) Dunstan DW, Vulikh E, Owen N, et al.: LinksCommunity centerbased resistance training for the maintenance of glycemic control in adults with type 2 diabetes. Diabetes Care, 2006, 29: 2586-91.

20) あずさ監査法人 (編) : 原価計算による病院マネジメント(第 3 版) DPC時代に向けた診療科別・疾患別原価計算 第 5 章自治 体病院における一般医療之政策医療の区分把握. 中央経済 社, 東京, 2004. 